\title{
Challenges to Engaging Students in the Management of Secondary Schools in Kenya
}

\author{
Tom M. Omtondo ${ }^{1}$, Joyce W. Kanyiri ${ }^{2}$, Peter Barasa ${ }^{3}$ \\ Doctoral Student, School of Education, Department of Educational Management and Policy Studies, MoiUniversity, Eldoret, Kenya \\ Senior Lecturer, Moi University, School of Education, Department of Educational Management and Policy Studies, Eldoret, Kenya \\ Department of Curriculum, Instruction and Educational Media School of Education, Moi University, Eldoret, Kenya
}

\begin{abstract}
The involvement of students' leaders in school management is seen as a precursor to stability and overall school success. Stability in learning institutions is a fact that immensely contributes to the realization of the learning institution's goals and objectives. School Prefects have been in place for a long time with the sole purpose of acting as a link between the teachers, school management and fellow students. In a recent development, a student representative will be required to be on the Board of Management as an exofficio member according to the basic education Act 2013. Despite the bold steps aimed at ensuring harmony in secondary schools through student inclusivity in decision-making, cases of student unrests are still prevalent within secondary schools in Kenya. This study investigated the extent of the involvement of the student's representative councils in the management of secondary schools in Kisumu County, with specific focus on the challenges to involvement of the student's representative councils in secondary school management. The study was guided by Douglas Mc. Gregor's Theory Y which encourages participatory approach to management. The study involved 199 public secondary schools that have existed for at least five years. The respondents, who included the principal, deputy principal, board of management chairperson and student leaders were drawn from 60 secondary schools. Data were collected by use of questionnaires, document analysis, and observation. This study adapted a descriptive survey research design aimed at collecting information from respondents on their attitudes and opinions in relation to integration of the students' representative councils in secondary schools management. The data collection instruments were questionnaires, document analysis guide and observation schedule. Data were analyzed by use of SPSS and subjected to a chi-square test for verification. Qualitative data were taken through content analysis. The study found that there are significant challenges to integration of students' representative councils in secondary schools management, namely absence of council offices and board rooms. This study recommends that the members of the students' council be inducted into the performance of their roles, students' council offices and boardrooms be part of the school physical infrastructure, and that further research be conducted focusing on the challenges to involvement of the students council as pertains academic excellence in secondary schools be conducted.
\end{abstract}

Keywords: Engaging Students in the Management of Secondary Schools

\section{Background of the Study}

According to Revees (1962), Management is the utilization of physical and human resources through co-operative efforts.Hersey and Blanchard (1977) define management as a process of working with individuals and through groups of people to achieve organizational goals. Leon Lessinger (1978), sees administration and management as separate entities. In administration, an organization has no explicit results to achieve, while in management, the organizations goals are explicitly defined.African countries, like many of the developing countries, placed considerable importance on education to promote economic and social development after independence (Sifuna, 2006).Prieto (2009), points out that education has been relied upon to establish and equip future man power with the requisite skills and knowledge, and to inculcate values which contribute to the enrichment of essentials for the maintenance of cohesive productivity. It was believed therefore that economic development could be accelerated using schools to develop the types of knowledge, skills and values that have proved useful in the industrialized nations (Barasa, 2007).

Since Kenya attained independence in 1963, it has committed itself to improving the standards of education at all levels in the belief that education, apart from being a human right it is a social vaccine in the fight against poverty, and a means to achieving the goals of national development, integration and peace (Suri \&Kalapana, 2008). To this end there have been various amendments and improvements in the way education is managed.

Educational Management has been among the issues given focus as a possible way to improving educational outcomes. The management policies and practices in place influence the performance of a firm (Zimmermann, 2002). That effective management is possible to greatly improve a situation.

Participatory management entails involving individuals or groups who have a stake, or claim in how well the organization performs, including investors, directors, managers, employees, unions, customers, creditors, the community, the state and region, and the society in general. Organizational environments are constantly changing, and therefore organizations must be modified accordingly to ensure that organizational goals can be attained (Peter \&Certo, 1993). In education, participatory management has been popularized as the best way to go by involving all the stakeholders as far as educational issues are concerned. Students too are expected to be involved in some way in school management since they are the direct beneficiaries. In secondary schools, the involvement of the students' council in management with focus on its formation, roles, rewards and privileges and relationship with school management have been encouraged as means to promoting good management but the challenges facing the integration of the 


\section{International Journal of Science and Research (IJSR) \\ ISSN (Online): 2319-7064}

Index Copernicus Value (2015): 78.96 | Impact Factor (2015): 6.391

student representative council have not been empirically established.

\section{Statement of the Problem}

A Student's Council is a representative structure for students only, through which they can become involved in the affairs of the school, working in partnership with school management, staff and parents for the benefit of the school and its students. (http: en.wikipedia.org/wiki/studentscouncil). The students' council is responsible for passing on requests, ideas and complaints from students to the school management. The student representatives are usually elected from and by the students' body although there may be prerequisites for candidacy.

While the mode of putting in place student leaders has changed, students have all along been engaged in school governance but despite this, there have been unrests in schools as students still feel inadequately considered in the management of the schools. Recently, among other recent incidents of unrests, asecondary school in Kakamega North district was closed indefinitely after students went on rampage, destroying property complaining over poor meals. The learners also demanded the transfer of the head teacher claiming he had been at the school for too long (Kitelu, 2014).

Police in Kwale County arrested five girls in connection with a mysterious dormitory fire at a Girls Secondary School in Kinango Sub-County.Kinangopolice boss said the girls were helping police with investigation and were to be charged with arson if found culpable. The girls were picked up as education officials, teachers and parents held a crisis meeting at the school. A fierce fire swept through a dormitory at the school, 15 years after a similar incident left 25 girls dead. In March 2014, the European Union completed a dormitory worth Ksh.5.4 million to accommodate 80 students. The institution had formerly been known byanother namebefore the March 1998 fire. (Beja, 2014). Three students in a Secondary School in Makueni County were on $30^{\text {th }}$ July, 2014 charged with arson. The three were arrested after setting the boys dormitory on fire, destroying property worth more than Ksh.4 million. Area Police Chief said the dormitory, with 124 double-deck beds, was completely destroyed. The school had 461 students. (Baraza, 2014). Therefore, this study will examine the integration of the students' representative councils in relation to the management of secondary schools.

\section{Purpose of the Study}

The purpose of this study was to investigate the challenges toengaging the student's representative councils in the management of secondary schools in Kenya, by taking the case of Kisumu County.

\section{Objective of the Study}

The objective of this study was to:

Assess the challenges facing members of thestudents' representative council,in secondary school management.

\section{Research Question}

This study intended to answer the following question:
Are there challenges to the involvementof the students representative councils in management of secondary schools?

\section{Research Hypothesis}

There are no significant challenges to involvement of the members of the student's representative councils in the management of secondary schools

\section{Rationale of the Study}

Management of schools in Kenya and the world over continues to pose challenges to the managers. The challenges are as a result of the ever changing nature of the society. The challenges arising from the schools' internal and external environments affect the school's every aspect and therefore impact on the school effectiveness in realizing its goals either positively or negatively. In order to cope with these developments, various trends in school reforms have been witnessed among these being reform in the way schools are managed. In Kenya, the Cabinet Secretary for education is responsible for the overall governance and management of basic education and for effectiveness, establishes structures of governance and management in education which among other duties will be required to enhance the culture of democracy, accountability and transparency in the governance and management of basic education. This is aimed at ensuring an enabling environment for teaching and learning which cannot take place in a chaotic environment which often is a result of students' unrest. The student's representative councils through which students participate in school management are aimed at resolving and curbing the thorny issue of student's unrest. Identifying the challenges to the functionality in in the involvement of the students representative councils in secondary school management will no doubt help improve management.

\section{Significance of the Study}

The study will serve several purposes. Firstly, it will provide knowledge and Literature for future researchers in related area. It will also provide an understanding that could effect a shift in school management. This study should assist the Ministry of Education, the Teachers Service Commission, Management of Secondary Schools, sponsors, and other stakeholders with the necessary information required in the management and smooth running of secondary schools. The recommendations are expected to address challenges faced by the students' representative councils.

\section{Assumptions of the Study \\ It was clear to the researcher that there were some other factors such as individual differences of the members of the students representative councils, differences in the nature of the schools, the environments in which they exist, and political factors among others that could also affect the involvement of the students representative councils in the management of secondary schools in Kenyabut the researcher was not interested in these other factors at the moment because their inclusion would widen the scope of the study and interfere with focus.}

These other factors are usually uniformly distributed across populations and could not be expected to significantly

\section{Volume 6 Issue 7, July 2017 www.ijsr.net}




\section{International Journal of Science and Research (IJSR) \\ ISSN (Online): 2319-7064}

Index Copernicus Value (2015): 78.96 | Impact Factor (2015): 6.391

influence the results of this study. The study therefore assumed that factors such as individual differences of the membersof the students' representative councils, differences in the nature of the schools, the environments in which they exist, and political factors among others did not contribute significantly to the involvement of the students' representative councils in the management of secondary schools. The researcher also assumed that the necessary requirements for research would be met in good time and that all the respondents would cooperate.

\section{Scope of the Study}

This study investigated the extent of the integration of the student's representative councils in the Management of Secondary Schools in Kisumu County, but with specific focus on challenges to the student's representative councils insecondary school management. The study was guided by the Gregory McGregor's Y theory of management, and conducted through a descriptive survey research design on a sample of 60secondary schools in Kisumu County. This study was conducted during the year 2015. Data were collected using questionnaires, interviews, observation and document analysis methods and analyzed using descriptive and inferential statistics and reported using tables and text...

\section{Theoretical Framework}

Organizations differ in the nature of the systems they develop and maintain and in the results they achieve.Varying results predictably follow from different models of organizational behavior. These models constitute the belief system that dominates management's actions in each organization. It is highly important that managers recognize the nature,significance and effectiveness of their own models as well as the models of others around them (Newstrom, 2010).

Performance of an organization is influenced by the management policies and practices in place (Zimmermann, 2002). Zimmermann argues that management also influences the performance of the economy at the level of the organization in aggregate and that ".... With effective management, it is possible to greatly improve ......... a situation" (p22). School Administration should therefore, be guided by the general theories and principles of management. This study was guided by Douglas MC Gregor's Theory Y. (McGregor, 1960). Mc Gregor points out that expenditure of physical and mental effort in work is as natural as play or rest. Control and punishment are not the only ways to make people work and that man will direct himself if he is committed to the aims of the organization especially if the job is satisfying and further observes that the average man learns under proper conditions not only to accept but seek responsibility and imagination, creativity, and ingenuity can be used to solve work problems by a large number of employees. Participative managers consult with their employees bringing them in on problems and decisions so that they work together as a team. The managers are not autocrats, but neither are they managers who abandon their management responsibilities. They still retain ultimate responsibility for the operation of their units, but they have learned to share operating responsibility with those who perform the work. This model further emphasizes the fact that for the possibility of obtaining commitment to the organization's objectives, it is better to explain the matter fully so that employees grasp the purpose of an action which will make them extend self-direction and control to do better work possibly by better methods than if they had been carrying out an order which they did not fully understand. This participative approach produces better results than the alternative approach of handing out authorization orders. The overriding consideration here is the fact that, staff will contribute more to the organization if they are treated as responsible and valued employees.

Likert (1967), supports this view by observing that... for an organization to achieve maximum profitability, good labour relations and high productivity, every organization must make optimum use of their human assets, but he contends that the form of the organization which will make greatest use of the human capacity is one with highly effective work groups linked together in an overlapping pattern by other similarly effective groups. Participative group system is the optimum solution, where leadership is by superiors who have complete confidence in their subordinates, where motivation is by economic rewards based on goals which have been set in participation, where personnel at all levels feel real responsibility for the organizational goals, where there is much communication, and a substantial amount of cooperative teamwork.

\section{Challenges to involving the students' Representative council in Management of secondary schools}

Students' indiscipline has been an issue of concern to management of schools for a long time. School managements will always make attempts to forestall any anticipated riots and unrests though sometimes they get overwhelmed and are left helpless when their efforts don't yield much. Feelings of neglect by the school management can lead to student unrests and reactive measures may not yield much. It is in this regard that managements of schools with the principals as their secretaries and the ones responsible for the day to day running of the schools have been grappling with the issue of forging better working relationships with the students for some time now. One of the pioneers of the students council model of leadership in secondary schools was the then Principal of Nairobi School between 2001 and 2010, Mr. Robert Masese who established the student council model of student leadership at Nairobi school and went ahead to open an office for the National Student Council at Nairobi School (KESSHA, 2011).

Due to the same concerns and student indiscipline and an attempt to forge a sound working relationship with the students so as to avoid unnecessary unrests and come up with a lasting solution, the KenyaSecondarySchools Heads Association (KESSHA) has had a series of meetings with other education stakeholders. Results from the meetings realized that cases of conflicts and indiscipline were deeplyrooted in how schools were administered, especially in the running of the student's affairs. The United Nations International Children's Education Fund (UNICEF) and the Ministry of Education found that radical reforms are required in student leadership as the way forward in addressing causes of tension in schools, which in most cases foment indiscipline culminating into violent strikes. This it

\section{Volume 6 Issue 7, July 2017 www.ijsr.net}




\section{International Journal of Science and Research (IJSR) \\ ISSN (Online): 2319-7064}

Index Copernicus Value (2015): 78.96 | Impact Factor (2015): 6.391

is thought would help arrest strikes by opening channels of communication in schools, cultivating a culture of dialogue and developing other non-violent disputes resolution mechanisms. The Ministry of educationand other stakeholders view the shift of student leadership from the prefects to a more representative body as imperative as it gives students a voice in their leadership, whiletransforming the roles of the prefects from masters to being a bridge of communication between students and school administration. A partnership started in 2008 between KESSHA and UNICEF led to the first ever secondary schools national student conference in 2009. These efforts culminated in the formation of the Kenya National Student Council that brings together student leaders from schools all over Kenya. The national students' council has been a major milestone in laying the ground work for the implementation of student councils in all public secondary schools in the country. With the advocacy and other efforts towards the reforms of student leaderships schools have taken steps to implement student councils (KESSHA, 2011).

\section{Related Studies}

There have been various studies on student leadership in educational institutions. The studies, including those of Etisi (2012), Duke (1989) and Combs (1995) have discussed the importance of attempts to involve students in school decision-making. They have indicated that the elected student leaders have the role of passing on requests, ideas and complaints to the school management. That when students believe they are contributing to the school environment in a significant way, they feel a more positive attachment to the school and are motivated to learn. Rules, Sanctions and procedures are discussed frequently before being formalized into school discipline. Students are therefore far more likely to develop good character and become accountable when they are provided an opportunity to learn and actively participate in a democratic learning environment through involvement.

Various scholars have also indicatedin their studies that violence in schools does not provide for a conducive environment in which to learn, (Boesel, 1978, Siegel \& Senna 1981, Rock, 1992, Craig, 1992, Murdick\& Barbara 1995, Okumbe, 1998, Babbie, 2008). They believe that this isdue to increase in domestic violence and child abuse resulting in frustration, school failure and retaliatory violence. That such children end up seeing adults as threatening rather than as supporters and providers of their innate needs. They tend to feel that they can protect themselves by bringing weapons to schools. That the children want to have a sense of control in their lives and as a result of the abuse or violence occurring within the home or community, many children may end up lacking feelings of control or routine in their lives.

When their needs of significance and competence are unmet they turn to violence to fulfill them. Students in secondary schools in Kenya tend to display similar tendencies when they feel neglected or ignored as far as their lives while at school are concerned. To inculcate self-discipline amongst the students, they therefore need to be listened to which is seen as a positive view about discipline (Okumbe, 1998).
Management of secondary schools in Kenya is taking this approach with the aim of addressing the problem of rampant student's unrests in secondary schools. The students are getting involved in school management through the student's representative council as one of them becomes a member of the BOM.

Scholars such as Okindaand Owuor (1995) appreciate the importance of student leaders and observe that they should be protected, guided and accorded privileges without vesting on them a lot of power. The privileges may include special meals and special school uniform. This study sort to determine the challenges to the members of the students' representative councils in secondary schools in relation to their involvement in secondary school management. Efforts by the Kenya Secondary Schools Heads Association, UNICEF and the Ministry of Education have led to the entrenchment of the students' representative councils in secondary schools management to assess the challenges facing members of the student's representative councils in their integration in secondary schools management. If this is done, the student leaders and by extension the entire student population will feel part and parcel of the school system and be at the forefront in providing safeguards against any interruptive activities likely to interfere with school work.

This chapter reviewed literature related to students' representative councils in secondary schools with a focus on the challenges to involvement of students' representative councils in secondary schools management. It was realized from the literature reviewed that; the common practice in learning institutions including secondary schools is that student leaders are democratically elected by fellow students, they have privileges accorded to them by their institutions, they have roles which include linking the students to the institutional management and, that institutions of learning, including secondary schools attempt to forge a working relationship with the students through the representative councils.

\section{Research Methodology}

This study applied both the use of quantitative and qualitative methods.

\section{Research Design}

This study adopted a mixed method approach using a cross sectional survey research design.

\section{Study Location}

This study was conducted in public secondary schools in the entire Kisumu County.

\section{Target Population}

This study targeted principals, deputy principals, student leaders and boards of management in public secondary schools in Kisumu County. There are 199 public secondary schools in Kisumu County; that have been in existence for at least the last five years. The target population therefore comprised of: 199 Principals, 199 deputy principals, 199 Student leaders, 199 members of boards of management. The total target population was therefore 796 .

\section{Volume 6 Issue 7, July 2017 www.ijsr.net}


International Journal of Science and Research (IJSR)

ISSN (Online): 2319-7064

Index Copernicus Value (2015): 78.96 | Impact Factor (2015): 6.391

Target Population

\begin{tabular}{|c|c|}
\hline Category & Target Population \\
\hline Principal & 199 \\
\hline Student leaders & 199 \\
\hline Members of Boards of Management & 199 \\
\hline Deputy principal & 199 \\
\hline Total & $\mathbf{7 9 6}$ \\
\hline
\end{tabular}

Source: (CDE’s office, 2015)

\section{The Sample Size and Sampling Procedures}

To arrive at an ideal sample size, $30 \%$ of the target population is recommended for a population of less than 1000 (Mugenda\&Mugenda, 2003). Therefore, the total sample size comprised of 240 respondents as illustrated in the table below;

Sampling Frame for respondents

\begin{tabular}{|c|c|c|c|c|}
\hline Categories & $\begin{array}{c}\text { Total } \\
\text { population } \\
\text { (schools) }\end{array}$ & Procedure & $\begin{array}{c}\text { Sampling } \\
\text { technique }\end{array}$ & $\begin{array}{c}\text { Sample } \\
\text { size }\end{array}$ \\
\hline Mixed day & 160 & $30 / 100 \times 160$ & Random & 48 \\
\hline Mixed boarding & 3 & $30 / 100 \times 3$ & Random & $0.9=1$ \\
\hline Girls only boarding & 21 & $30 / 100 \times 21$ & Random & $6.3=6$ \\
\hline Boys only boarding & 10 & $30 / 100 \times 10$ & Random & $3=3$ \\
\hline Girls day & 3 & $30 / 100 \times 3$ & Random & $0.9=1$ \\
\hline Boys day & 2 & $30 / 100 \times 2$ & Random & $0.6=1$ \\
\hline Total & 199 & & & $59.7=60$ \\
\hline
\end{tabular}

Source: (CDEs' office, author, 2015)

The researcher used the sampled schools to automatically get 60 Principals, 60 deputy principals, 60 student leaders, and 60 chairpersons of boards of management to be part of the sample. The sample therefore comprised of 240 respondents. The study selected four respondents from each of the selected schools.

\section{Data Collection Procedures}

Once the researcher obtained the necessary clearance and a letter of introduction from the school of Education of Moi University, the next step was to proceed to the National Council for Science,Technology and innovation for research authority. The researcher then booked appointments with the principals of the sampled schools. The purpose of the study was clearly explained to the respondents and assurance of confidentiality given, after which the data collection tools were administered.

\section{Data Collection Instruments}

The researcher collected data by the use of questionnaires, observation schedules, and document analysis guides.

\section{Questionnaires}

The researcher used questionnaires to collect data from principals, student representative council's leaders, boards of management representatives and deputy principals on the extent and challenges to functionality in the involvement of the student's representative councils in the management of secondary schools.

\section{Document Analysis Guide}

Document analysis was usedto collect data on the challenges in involving the student's representative councils in management of secondary schools in Kisumu County.

\section{Observation Schedule}

The researcher used structured observation to collect data on the offices for the members of the students' representative councils in the selected schools in Kisumu County.

\section{Validity of Research Instruments}

The researcher ensured validity of the instruments to be used in the study through expert assessment by experts in the Department of Educational Management and Policy Studies at Moi University and the necessary adjustments and corrections effected before proceeding for the actual data collection.

\section{Reliability of Research Instruments}

The researcher administered the instrument to a sample of 2 schools in the neighboringVihiga County (due to its proximity to Kisumu County), twice between two weeks and then correlated the results from the two administrations to calculate the consistency of the instruments. The scores from the two administrations were correlated using the Pearson product moment to find a reliability coefficient. For a reliability index to be acceptable, it should be at least 0.70 (Kathuri and Palls, 1993; Oso \&Onen, 2009), which means that out of any ten items, at least seven of them should produce consistent responses from the responses over time.

\section{Data Analysis Procedures}

This study adopted both qualitative and quantitative analysis since it engaged a mixed methods approach to research. Descriptive statistics were used to describe characteristics of participants in the sample (Ross, 2005). Data were then presented in tables and text. For qualitative data processing and analysis, content analysis technique was undertaken as an activity simultaneous with data collection. Firstly, the data were organized along key thematic areas and summarized. The responses were then described to produce interim reports, and areas that required additional information identified and the requisite data sourced. Data collected from the questionnaires werecoded into the statistical package for social sciences (SPSS) for analysis and also subjected to chi square test verification. There was then systematic analysis and interpretation of the interim report which was then integrated in the main report.

\section{Ethical Considerations}

The researcher concisely informed the participants of the purpose of the study as explained in the preliminary stages of this study, refrained from deceptive practices, was respectful of the research site, used ethical interview practices and maintained confidentiality.

\section{Data Presentation, Analysis, Interpretation and} Discussion

The study investigated the challenges toinvolving thestudents' representative council in the management of secondary schools in Kenya, by taking the case of Kisumu County. Data were collected using questionnaires from a random sample of student leaders, principals, deputy principals and the board of management in the period of May, to August 2015. Some data were collected by use of observation and document analysis. The study specifically investigated the challenges facing members of the students' 


\section{International Journal of Science and Research (IJSR) \\ ISSN (Online): 2319-7064}

Index Copernicus Value (2015): 78.96 | Impact Factor (2015): 6.391

representative council in the management of the schools. The intended sample was 240, but 199 respondents returned complete questionnaires. This was $82.92 \%$ which was more than the $70 \%$ response-return rate recommended in social science research (Oso, 2013).

Challenges to involving the Students Representative Councils in the management of Secondary Schools

This section reports on the involvement of the students' representative council in the management of secondary schools in Kisumu County. Involvement was conceptualized as the challenges to members of the students' representative council in secondary schools management. The problem of this study was that there was inadequate involvement of the students' representative council in the management of secondary schools, and that some factors must be responsible. However such factors were not known from an empirical perspective. This study proceeded deductively from a major premise that factors that influence involvement of students' representative council in the management of secondary schools are known, but their status may not be known. But if the status of the factors in a school is known, then it could be deduced from its status whether that factor is a challenge to involvement of the students' representative council in the management of secondary schools or not.

\section{Measurement of Variables}

The purpose of this study was to determine the influence of challenges facing members of the student's representative council in their involvement in the management of secondary schools in Kisumu County. The respondents were asked to react to statements on each variable by indicating Strongly Agree, Agree, Neither Agree nor Disagree, Disagree and Strongly Disagree. Strongly Agree was coded 5, Agree was coded 4; Neither Agree nor Disagree was coded; Disagree was coded 2; and Strongly Disagree was coded 1 . Variables were coded and scored as summarized in the Table below

Variable Codes and Scores

\begin{tabular}{|c|c|c|c|c|}
\hline Involvement & Variables & Score & Code & $\begin{array}{l}\text { Status of } \\
\text { Variable }\end{array}$ \\
\hline \multirow{5}{*}{$\begin{array}{l}\text { Challenges } \\
\text { facing members } \\
\text { of the students' } \\
\text { representative council. }\end{array}$} & $\begin{array}{l}\text { Strongly } \\
\text { Disagree }\end{array}$ & 3 & 1 & Very weak \\
\hline & Disagree & 5 & 2 & Weak \\
\hline & $\begin{array}{l}\text { Neither agree } \\
\text { nor Disagree }\end{array}$ & 2 & 3 & Moderate \\
\hline & Agree & 45 & 4 & Strong \\
\hline & Strongly agree & 41 & 5 & Very strong \\
\hline
\end{tabular}

Involvement of students' representative council in school management.

Challenges to Involvement of Students' Representative Council in School Management

The objective of this study was to determine the challenges to in involving the students' representative council in the management of secondary schools. Different categories of the respondents were asked to indicate their views on the challenges to integration of students' representative council in the management of secondary schools, on a Likert scale. The responses obtained are summarized in the Table below:
Challenges to Involvement of Students' Representative Councils in School Management

\begin{tabular}{|c|c|c|c|c|c|c|c|}
\hline & & \multicolumn{7}{|c|}{$\begin{array}{c}\text { Challenges to involving the students' } \\
\text { representative councils of } \\
\text { schools management }\end{array}$} & \\
\hline $\begin{array}{c}\text { Respondent } \\
\text { Category }\end{array}$ & & UND & DA & SDA & A & SA & Total \\
\hline Principal & Count & 0 & 0 & 1 & 16 & 9 & 26 \\
\cline { 2 - 9 } & Percent & .0 & .0 & 1.0 & 16.7 & 9.4 & 27.1 \\
\hline \multirow{2}{*}{ D/ Principals } & Count & 1 & 0 & 1 & 15 & 7 & 24 \\
\cline { 2 - 9 } & Percent & 1.0 & .0 & 1.0 & 15.6 & 7.3 & 25.0 \\
\hline $\begin{array}{c}\text { BOM - } \\
\text { Chairman }\end{array}$ & Count & 1 & 3 & 0 & 9 & 12 & 25 \\
\cline { 2 - 9 } & Percent & 1.0 & 3.1 & .0 & 9.4 & 12.5 & 26.0 \\
\hline \multirow{2}{*}{ S/ Leaders } & Count & 0 & 2 & 1 & 5 & 13 & 21 \\
\cline { 2 - 9 } & Percent & .0 & 2.1 & 1.0 & 5.2 & 13.5 & 21.9 \\
\hline \multirow{2}{*}{ Total } & Count & 2 & 5 & 3 & 45 & 41 & 96 \\
\cline { 2 - 8 } & Percent & 2.1 & 5.2 & 3.1 & 46.9 & 42.7 & 100.0 \\
\hline
\end{tabular}

Note. UND = Undecided; DA = Disagree; SDA = Strongly Disagree; $\mathrm{A}=$ Agree; $\mathrm{SA}=$ Strongly Agree.

The table above shows the responses of principals, deputy principals, BOM - Chairmen and student leaders on the challenges to involvement of students' representative council in school management. Most principals surveyed $(16.7 \%)$ agreed that there are challenges ininvolving thestudents' representative council in school management while another $9.4 \%$ of the principals strongly agreed. None of the principals surveyed $(0.0 \%)$ disagreed that there are challenges in involving the students' representative council in school management while one of the principals surveyed $(0.0 \%)$ were undecided on whether there are challenges in the involvement of students' representative council in school management. Generally, most principals surveyed (26.1\%) were of the view that there are challenges to involvement of students' representative council in school management, and only one principal $(1.0 \%)$ of the principals surveyed opposed this position.

The same question was put to deputy principals. Most of the deputy principals surveyed $(15.6 \%)$ agreed that there are challenges to involvement of students' representative council in school management while another $7.3 \%$ strongly agreed. Only $1.0 \%$ of deputy principals surveyed strongly disagreed that there are challenges to involvement of students' representative council in school management. Another $1.0 \%$ of the deputy principals surveyed were undecided. On the overall analysis, most deputy principals surveyed $(22.9 \%)$ were of the view that there are challenges to involvement of students' representative council in school management while only $1.0 \%$ disagreed. Hence deputy principals generally supported the position that the there are challenges to involvement of students' representative council in school management.

Most of the BOM - chairpersons surveyed (12.5\%) strongly agreed that the there are challenges to involvement of students' representative council in school management while $9.4 \%$ agreed. Further, $3.1 \%$ of BOM - chairmen surveyed disagreed that there are challenges to involvement of

\section{Volume 6 Issue 7, July 2017 www.ijsr.net}




\section{International Journal of Science and Research (IJSR) \\ ISSN (Online): 2319-7064}

Index Copernicus Value (2015): 78.96 | Impact Factor (2015): 6.391

students' representative council in school management. Only (1.0\%) BOM - chairman surveyed was undecided on whether there are challenges to involvement of students' representative council in school management. Generally, most BOM - chairmen surveyed (21.9\%) indicated that are challenges to involvement of students' representative council in school management. Only $3.1 \%$ of the BOM chairmen surveyed felt that there are no challenges to involvement of students' representative council in school management. Generally, the BOM-Chairmen were of the view that there are challenges to involvement of students' representative council in school management.

The table also shows that most student leaders surveyed $(13.5 \%)$ strongly agreed that there are challenges to involvement of students' representative councils in school management while $5.2 \%$ of the student leaders agreed with this position. Further, $2.1 \%$ of student leaders surveyed disagreed, that there were challenges to involvement of students' representative council in school management; while none $(0 \%)$ of the student leaders surveyed were undecided on whether there were challenges to involvement of students' representative council in school management. Generally, most student leaders surveyed (18.7\%) were of the view that there are challenges to involvement of students' representative council in school management and $8.3 \%$ of the student leaders surveyed felt that there are no significant challenges to involvement of students' representative council in school management. Generally, the student leaders were of the view that the there are challenges to involvement of students' representative council in school management. The challenges identified include provision of special meals, provision of refreshments during meetings, involvement in the daily school running, taking student leaders for trips, provision of free special uniforms, availability of Boardrooms and council offices.

Data on the last row of table 4.9 shows the total responses of all respondents, principals, deputy principals, BOM Chairmen and student leaders on challenges to involvement of students' representative council in school management. Most respondents $(42.7 \%)$ strongly agreed that there are challenges to involvement of students' representative council in school management while $46.9 \%$ of the respondents agreed on the same. But $5.2 \%$ of the respondents disagreed that there are challenges to involvement of students' representative council in school management while $3.1 \%$ of the respondents strongly disagreed. But only $2.1 \%$ of all respondents were undecided on whether there are challenges to involvement of students' representative council in school management. On the overall analysis, most respondents $(89.6 \%)$ were of the view that there are challenges to involvement of students' representative council in school management while only a small proportion of $8.3 \%$ generally disagreed. It was deduced from these results that there are significant challenges to involvement of students' representative councils in school management.

The data above was subjected toa chi square test of goodness-of-fit to test the hypothesis that there is no significant difference in the opinions of staff of secondary schools on challenges to involvement of students representative council in school management.

There are no significant challenges to involvement of the members of the students' representative councils in the management of secondary schools in Kisumu County.

The results of the analysis are summarized in below

$\chi^{2}$ Results of Views on Challenges to Involvement of Students' Representative Councils in School Management

\begin{tabular}{|c|c|c|c|c|c|c|}
\hline Variable & $\mathrm{N}$ & $\mathrm{df}$ & $\chi^{2}$ & Sig. & Cramer's V & Decision \\
\hline $\begin{array}{c}\text { Challenges to } \\
\text { integration }\end{array}$ & 199 & 12 & 174.390 & .034 & .246 & Reject $\mathrm{H}_{04}$ \\
\hline \multicolumn{8}{|c|}{12 cells (60.0\%) have expected count less than 5. } \\
The minimum expected count is .44.
\end{tabular}

The above Table shows the results of chi-square test of the views of the respondents on the challenges to involvement of students' representative council in school management. It shows that $\chi^{2}(12, \mathrm{~N}=199)=174.390, p=.034$, which led to rejection of the null hypothesis. There were significant differences between number of the respondents who agreed that there are challenges to involvement of students' representative council in school management and those who disagreed. The hypothesis that there are no challenges to the involvement of students' representative council in the management of secondary schools in Kisumu County was therefore rejected. The finding suggested by the data in the Table above was therefore sustained. This means that the there are significant challenges to involvement of students' representative council in the management of secondary schools.

The Cramer's V Coefficient $(\mathrm{C}=.246)$ indicates that $24.6 \%$ of the involvement of students' representative council in the management of secondary schools in Kisumu County is dependent on the challenges. Therefore involvement of students' representative councils in school management can be improved by up to $24.6 \%$ if the challenges to involvement of the students' representative councils are properly identified and addressed, other factors notwithstanding.

\section{Key Challenges to involvement of Students' Representative Council in School Management}

Since the objective of this study revealed that there are significant challenges to involvement of students' representative council in the management of secondary schools, it was necessary to identify these key challenges. The key challenges identified as absence of students' representative council offices and absence of students councils board rooms. Different categories of respondents were asked to indicate their views on the main challenges to involvement of students' representative council in the management of secondary schools, on a Likert scale. The responses obtained are summarized in the Table below: 


\section{International Journal of Science and Research (IJSR) \\ ISSN (Online): 2319-7064}

Index Copernicus Value (2015): 78.96 | Impact Factor (2015): 6.391

Views on Students Representative Council Offices

\begin{tabular}{|c|c|c|c|c|c|}
\hline \multirow{2}{*}{$\begin{array}{c}\text { Respondent } \\
\text { Category }\end{array}$} & & \multicolumn{4}{|c|}{$\begin{array}{r}\text { Status of students' representative } \\
\text { councils offices }\end{array}$} \\
\cline { 3 - 6 } & & Adequate & Inadequate & Unavailable & Total \\
\hline Principal & Count & 3 & 1 & 21 & 26 \\
\hline & Percent & 4.2 & 1.4 & 29.6 & 36.6 \\
\hline D/ Principals & Count & 4 & 2 & 18 & 24 \\
\hline & Percent & 5.6 & 2.8 & 25.4 & 33.8 \\
\hline S/ Leaders & Count & 3 & 3 & 15 & 21 \\
\hline & Percent & 4.2 & 4.2 & 21.1 & 29.6 \\
\hline Total & Count & 10 & 6 & 54 & 71 \\
\hline & Percent & 14.1 & 8.5 & 76.1 & 100 \\
\hline
\end{tabular}

Note. UND = Undecided $; \mathrm{DA}=$ Disagree $;$ SDA = Strongly Disagree; $\mathrm{A}=$ Agree; $\mathrm{SA}=$ Strongly Agree .

The Table shows the responses of principals, deputy principals, and student leaders on the status of students' representative council's offices as a challenge to involvement of students' representative council in school management. Most principals surveyed (29.6\%) indicated that students' representative council's offices are unavailable while only $5.6 \%$ indicated that students' representative council offices were available. But most deputy principals surveyed $(25.4 \%)$ indicated that students' representative council's offices were unavailable while only 4.2 indicated that students' representative council offices were available. Most student leaders surveyed $(21.1 \%)$ indicated that students' representative council's offices were unavailable while only 4.2 indicated that students' representative council offices were available.

Most respondents (76.1\%) indicated that students' representative council offices were unavailable while only $14.1 \%$ indicated that students' representative council offices were available. It was deduced from these results that students' representative council offices were unavailable in most schools.

The data above was subjected to chi square test of goodnessof-fit to test the hypothesis that there is no significant difference in the opinions of staff of secondary schools on challenges to involvement of students' representative council in school management.

There are no significant challenges to involvement of the members of the students' representative councils in the management of secondary schools in Kisumu County.

The results of the analysis are summarized below $\chi^{2}$ Results of Views on Challenges to Involvement of Students' Representative Councils in School Management

\begin{tabular}{|l|c|c|c|c|c|c|}
\hline Variable & $\mathrm{N}$ & $\mathrm{df}$ & $\chi^{2}$ & Sig. & Cramer's V & Decision \\
\hline $\begin{array}{l}\text { Challenges to } \\
\text { involvement }\end{array}$ & 199 & 12 & 174.390 & 0.34 & .246 & Accept $\mathrm{H}_{04}$ \\
\hline
\end{tabular}

Data above shows the results of chi-square test of the views of the respondents on the challenges to involvement of students' representative council in school management. It shows that $\chi^{2}(12, \mathrm{~N}=199)=174.390, p=.034$, which led to rejection of the null hypothesis. There were significant differences between number of the respondents who agreed that there are challenges to involvement of students' representative council in school management and those who disagreed. The hypothesis that there are no challenges to the involvement of students' representative council in the management of secondary schools in Kisumu County was therefore rejected. The finding suggested by the data above was therefore sustained. This means that there are significant challenges to involvement of students' representative council in the management of secondary schools.

The Cramer's V Coefficient $(\mathrm{C}=.246)$ indicates that $24.6 \%$ of the involvement of students' representative council in the management of secondary schools in Kisumu County is dependent on the challenges. Therefore involvement of students' representative councils in school management can be improved by up to $24.6 \%$ if the challenges to involvement of the students' representative councils are properly identified and addressed, other factors notwithstanding.

Other factors identified to enhance involvement of the student's representative councils in secondary school management include; provision of special meals, provision of refreshments during meetings, involvement in the daily school running, taking student leaders for trips, and provision of free special uniforms.

\section{Discussion}

This study pursued one specific objective, and consequently made one major finding on the objective. There were however, other subsidiary or minor findings. The study found that there are significant challenges to involvement of the students' representative council in school management. This was occasioned by the fact that most respondents $(89.6 \%)$ were of the view that there are challenges to involvement of student's representative council in school management while only $8.3 \%$ generally disagreed. A chisquare test revealed that $\mathrm{x}^{2}(12, \mathrm{~N}=199)=174.390, \mathrm{P}=.034$ and sustained the finding that there are significant challenges to involvement of students' representative council in the management of secondary schools.

\section{Summary of Findings}

This study investigated the challenges to involvement of the students' representative council in management of secondary schools. Different categories of respondents were asked to indicate their views on the challenges to involvement of students' representative council in the management of secondary schools on a Likert scale. From the results of the analysis it was deduced that there are significant challenges to involvement of students' representative council in school management. A chi-square test sustained the finding that there are significant challenges to involvement of students' representative council in the management of secondary schools. These challenges, the study found that they include absence of the student's representative council offices and boardrooms.

\section{Volume 6 Issue 7, July 2017 www.ijsr.net}




\section{International Journal of Science and Research (IJSR) \\ ISSN (Online): 2319-7064}

Index Copernicus Value (2015): 78.96 | Impact Factor (2015): 6.391

\section{Conclusion}

The purpose of this study was to investigate the involvement of student's representative council in the management of secondary schools in Kenya, by taking the case of Kisumu County with specific focus on the influence of the challenges to involvement of the students' representative councilin management of secondary schools.

In line with the purpose, and objective of the study and following the summary of findings, the study concludes that the process of formation of students' representative council if well followed and adhered to will lead to adequate involvement of the students' representative council in school management. Thus, the monitoring and streamlining of this process should be addressed as a priority such that the students of secondary schools are allowed to elect their students' The study concludes that there are significant challenges to involvement of students' representative council in school management which if properly identified and addressed, will improve involvement of the students' representative council in management of secondary schools. The challenges include the fact that the students' representative council offices and boardrooms were unavailable in most schools.

\section{Recommendations}

Based on the findings and the conclusions drawn above, the study makes the following recommendations.

1) To improve involvement of the students' representative councils in the management of secondary schools this study recommends that the Ministry of Education Science and Technology facilitates provision of students' representative council offices and boardrooms in all secondary schools to enable them run their activities more efficiently.

2) The school principals should ensure that the roles of the members of the students' representative councils are properly articulated and structured by ensuring induction and orientation for the student's representative councils into their roles and responsibilities for harmony between the student's representative councils, the rest of the students and the entire secondary school community.

3) A similar study be conducted on a larger scale to cover the whole country.

\section{References}

[1] A collection of articles (1995) IRI/Sky light training and publishing, Inc. USA

[2] Babbie, E. (2008). The Basics of Social Research. Thomson Higher Education, 10 Davis Drive Belmont, CA 94002-3098 USA

[3] Barasa, J. M.(2007). Educational Organization and Management. The Jomo Kenyatta Foundation, Nairobi, Kenya

[4] Baraza, J. (2014, July 31). Students charged with dormitory arson. The Daily Nation p.11

[5] Basic Education ACT, No. 14 of 2013. Nairobi: GoK

[6] Beja, P. (2014, July 30). Five (5) girls arrested over dormitory inferno. The Standard p.10
[7] Boesel, D. (1978). Violent Schools - Safe Schools: The Safe School Study Report to the Congress. Vol. 1. Washington, D.C.: National Institute of Education.

[8] Certo, S. C. \& Peter, J. P. (1993). Strategic Management. A Focus on Process. Burr Ridge: Irwin.

[9] Craig, S.E. (1992). The Educational Needs of Children living with violence. Phi Delta Kappan

[10]Dewey, J. (1917). Democracy and Education. (htt//en.wikipedia.org/wiki/student-council downloaded on $8 / 12 / 2013$ at $12: 17 \mathrm{pm}$ )

[11] Duke, D. L. (1989). 'School Organization, Leadership, and students behaviour' Strategies to reduce student misbehaviour

[12]Etisi, M. Z. (2012). The tested strategies of curbing student indiscipline in Learning institutions. Shrend Publishers Ltd.

[13]Hersey, P. \& Blanchard, K. (1977) Management of OrganisationBehaviour: Utilizing Human Resources. New Jersey: Englewood - Cliffs, Prentice - Hall, Inc

[14] Htt://en.wikipedia.org/wiki/student-council downloaded on $8 / 12 / 2013$ at $12: 17 \mathrm{pm}$

[15] Kathuri, N. J., \& Palls, A. D. (1993). Introduction to educational research. Egerton University Education Book series.

[16] Kenneth, N. Ross (2005) quantitative research in educational planning. International Institute of Educational Planning. Paris, France, UNESCO

[17] KESSHA (2011). The Principal; Secondary Schools Heads Professional Magazine, (June 2011 Issue P.20)

[18] Kitelu, J. (2014, February 19). School closed after students go on strike. The Daily Nation p.19

[19] Kothari, C. (2007). Research Methods and Techniques. New Delhi: KishaPraka Sham

[20] Lessinger, L. (1978). "The Management of Curriculum and Instruction: Producing the student who is capable of being useful". Speech made at the meeting of American Association of School Administrators, Minneapolis, Minnesota

[21]Likert, R. (1967). The Human Organization. New York: McGraw-Hill.

[22] McGregor, D. (1960). The human side of Enterprise. New York: McGraw-Hill.

[23] Ministry of Education (2013). Basic Education Act. Nairobi: Government Printer.

[24] Mugenda, O.M\&Mugenda, A. G. (2003). Research Methods: Quantitative and Qualitative Approaches. Nairobi: African Centre for Technology Studies.

[25] Murdick, N. \& Barbara, G. (1995). How to handle students exhibiting violent behaviours. In Burke \& Kay, (Eds.), managing interactive classroom: A Collection of articles.

[26] Newstrom, J. W. (2010). Organizational Behaviour. New York:McGraw-Hill.

[27] Okinda, E. \& Owuor, W. (1995). Guidelines to Successful Teaching and Headship in Schools and Colleges World Link, Nairobi.

[28] Okumbe, J. A. (1998). Educational Management Theory and Practice. Nairobi University Press

[29] Oso, W. Y. \&Onen, D. (2009). A general guide to writingResearch Proposal and Report (Rev. ed) Nairobi: Jomo Kenyatta Foundation. 


\section{International Journal of Science and Research (IJSR) \\ ISSN (Online): 2319-7064}

Index Copernicus Value (2015): 78.96 | Impact Factor (2015): 6.391

[30] Oso, W. Y. (2013). A general guide to writingResearch Proposal and Report (Rev. ed) Nairobi: Jomo Kenyatta Foundation.

[31] Prieto Gutie'rvez, Juan Jose' (2009) Security Library Seguridadenbibliotecas. Seguritecnia, revistadecanaindependiente de seguridad, Julio-agosto (355). Pp.60-64. ISSN 0210 - 8747

[32] Republic of Kenya, Ministry of Education Science and Technology. Report of the Task Force on Student Discipline and Unrest in Secondary schools, September, 2001. Published by theJomo Foundation, Nairobi; Kenya

[33] Reeves, A. W. (1962). Educational Administration: The Role of the Teacher. Toronto: Mac Millan

[34] Rock, E. E. (1992). High incidence behavior disorders. In educating students with behaviour disorders, edited by M. S. Rosenberg, R. Wilson, L. Maheady, and P. T. Sindelar, 35-85 Boston: Allyn and Bacon

[35] Siegel, L. J., \& J. J. Senna (1981) Juvenile delinquency: Theory, Practice, and law. New York: West.

[36] Sifuna, D. N. (2006). An introductory history of education. (Rev. ed). Nairobi: UOP

[37] Suri, R. K., Kalapana, R. (2008). Infrastructure: $S \& T$ Education, Sci. Technol. Third world, edited New Delhi: Spectrum, ISBN 81-7938-294-6)

[38] UNICEF (2010). Child friendly schools

[39]Zimmerman, F. M. (2002). Cornerstones of Management. Old recipe for today's problems. NP.

Volume 6 Issue 7, July 2017

www.ijsr.net 